\title{
Nationale mindretal i Nord- og Sydslesvig
}

\author{
- en model for nationale mindretals politiske status*
}

\section{af Jørgen Elklit og Ole Tonsgaard}

I samfundsvidenskaberne studeres den politiske og historiske virkelighed og udvikling ofte med det formål at konstatere generelle mønstre for fænomener og udviklingsforløb. Også de nationale mindretal i Slesvig - især det tyske i Nordslesvig, i mindre omfang det danske i Sydslesvig og endnu mindre det frisiske - er blevet studeret under en samfundsvidenskabelig tilgangsvinkel. Jørgen Elklit og Ole Tonsgaard, lektorer ved Institut for Statskundskab ved Aarhus Universitet, præsenterer og diskuterer her de ordninger, der har været bragt $i$ anvendelse til regulering af de slesvigske mindretals eksistens og politiske forhold. Forfatterne spørger også, hvilke følger disse ordninger kan tænkes at få for det danske og det tyske mindretal i fremtiden. Artiklen påpeger, at mindretallene står over for en vanskelig konflikt: Modsætningen mellem ønsket om at fastholde det egne kulturelle særpræg og ønsket om såvel økonomisk-social som politisk ligestilling med det omgivende samfund. Forfatterne har tidligere skrevet om mindretalsforhold, især med udgangspunkt $\mathrm{i}$ det tyske mindretals situation.

Formålet med denne artikel er at præsentere og diskutere de forskellige ordninger, der er gennemført for at løse problemerne omkring de slesvigske mindretals politiske status. På baggrund af aktuelle udviklingstendenser vil mindretallenes fremtidige situation blive drøftet, og afslutningsvis vil diskussionen blive søgt udmøntet i nogle teoretiske generaliseringer.

I det første afsnit præciseres nogle grundbegreber, og der opstilles en teoriramme for den videre drøftelse. Derefter præsenteres i afsnit 2 fem typer af løsningsmodeller for nationale mindretals politiske status, modellernes forudsætninger fremhæves, og der gives nogle eksempler på deres anvendelse.

Den nærmere drøftelse af de slesvigske mindretal findes i afsnit 3; i det følgende afsnit redegøres derefter for de ordninger, der er gennemført for at løse problemerne omkring mindretallenes politiske status. Med udgangspunkt $i$ aktuelle udviklingstendenser drøftes derefter $i$ afsnit 5 den fremtidige situation ikke blot med henblik på den politiske status, men også mere generelt.

\footnotetext{
- Artiklen er en revideret og lidt forkortet version af et indlæg til symposiet $m A ̊ l a n d$, självstyrelsesregioner, europeiska minoriteter«, som blev afholdt i Mariehamn af Nordens Institut på Åland 25.28. august 1988. Revisionen har nydt godt af konstruktive kommentarer fra såvel Henrik BeckerChristensen, Andreas P. Cornett, Hans B. Feddersen, Johan Peter Noack og Erik Rasmussen som Sønderjyske Årbøgers redaktion.
} 
Da forholdene i det slesvigske område også kan betragtes som et resultat af mere grundlæggende sociale processer, vil der til sidst - i afsnit 6 - blive gjort et forsøg på at udmønte resultaterne af diskussionen i nogle få mere teoretiske generaliseringer.

\section{Nationale mindretal - nogle grundbegreber og teoretiske betragtninger}

Udgangspunktet for en hensigtsmæssig definition af nationale og etniske mindretal må efter vor opfattelse være, at der dels skal være tale om sociale systemer ${ }^{1}$ med en selvstendig kultur, dels - naturligvis - at de pågældende sociale systemer eller grupper skal udgøre talmæssige mindretal inden for større sociale sammenhænge. ${ }^{2}$

Det vigtigste element $i$ denne definition er den selvstændige kultur, hvor kultur defineres som et fælles mønster af erfaringer, opfattelser, vurderinger, viden og holdninger, der eksisterer i tilknytning til et socialt system. Det enkelte menneske er kun i et vist omfang bærer af systemets kultur, som derfor ikke i denne sammenhæng skal ses som et indvidual-psykologisk fænomen. Kultur bliver følgelig en socialt fastsat definition af det sociale system og det samspil, der foregår inden for systemet.

Det er hensigtsmæssigt at bruge betegnelsen etniske grupper som en samlebetegnelse for de forskellige typer af grupper, som det på grund af deres selvstændige kultur og karakteren af de centrale elementer i den pågældende kultur er nødendigt at sondre imellem. Man kan således tale om etnisk-religiøse grupper, etnisk-nationale grupper, etniske sproggrupper osv. De etnisk-nationale grupper indtager $\mathrm{i}$ denne forbindelse en særstilling, idet en nationalgruppe per definition også må være en etnisk gruppe.

Når talen er om nationale mindretal, kan man sondre mellem grænseflytningsmindretal, immigrantmindretal og oprindelige befolkninger.

De tre betegnelser viser alle hen til væsentlige elementer i begrebsindholdet. Granseflytningsmindretal er opstået ved, at nationalgrænser er ændret, således at befolkningsgrupper er blevet afskåret fra den nationalstat - og dermed den nationale kultur - de føler sig som en del af. Den europæiske historie er rig på sådanne eksempler, og de to store mindretal i det slesvigske område er netop resultater af grænseflytninger mellem Tyskland og Danmark.

Områdets tredje mindretal, de nationale frisere, er derimod en oprindelig befolkning med en selvstændig kultur i forhold til den omgivende majoritetsbefolkning. En oprindelig befolkning som nationalt mindretal er naturligvis en relativ betragtning. Det bør her erindres, at nationalstaten som fænomen 
næppe er mere end 200 år gammel. Man kan derfor sige, at for $\mathrm{i}$ denne sammenhæng at blive betragtet som en oprindelig befolkning skal en befolkningsgruppe have beboet området $i$ lang tid, før national identitet og nationalt tilhørsforhold blev realiteter.

Immigrantmindretal kommer derimod kun i beskedent omfang på tale $\mathrm{i}$ denne forbindelse. De er imidlertid ifølge sagens natur det dominerende element i debatten om etniske og nationale mindretal i USA, og problematikken er selvfølgelig også kendt $i$ en europæisk sammenhæng. Det gælder dels historisk, dels aktuelt, hvor efterkrigstidens flygtninge- og indvandrergrupper er eksempler på egentlige immigrantmindretal. Sådanne mindretal er stadig af væsentlig betydning mange steder i Europa, men da deres forhold er ret specielle i forhold til denne artikels problemstilling, vil vi som nævnt ikke gå nærmere ind på denne type af mindretal.

Uanset deres oprindelse har mange nationale mindretal været begunstiget af en forholdsvis klar geografisk adskillelse fra flertalsbefolkningen, hvad der har haft betydning for gruppens overlevelse og fortsatte eksistens. Forklaringen er dels, at der så på alle livets områder har været mindre kontakt mellem flertal og mindretal - både individuelt og for grupperne under ét - end der ellers ville have været (den sociale segregation, eller madskilthed«), dels at mindretallene har haft behov for - og mulighed for - at oprette og råde over egne politiske, økonomiske, sociale og andre organisationer (den kollektive segregation). Såvel den mindre sociale kontakt som eksistensen af selvstændige organisationer fastholder og fremmer måske også den kulturelle adskillelse og opsplittethed mellem flertal og mindretal, som efter definitionen ovenfor er grundbetingelsen for et nationalt mindretals fortsatte eksistens. ${ }^{3}$

I anden sammenhæng har vi argumenteret for, at den afgørende faktor for, om de nationale mindretal er præget af stabilitet eller af tendens til nedbrydning - det vil sige kulturel assimilation - er mindretallets deltagelse i det økonomiske liv på lige fod med flertalsbefolkningen, altså den økonomiske assimilation. ${ }^{4}$

Det modsatte af økonomisk assimilation er ikke diskrimination, men derimod en situation, hvor mindretallet selv udgør et selvstændigt og afgrænset socialt system, der omfatter så mange væsentlige aspekter af tilværelsen som muligt - og herunder altså også væsentlige økonomiske aspekter. Et sådant delsystem kan meget vel være integreret $i$ det større nationale system, men en situation, hvor de enkelte medlemmer af mindretallet deltager stærkt - specielt på det økonomiske område - i flertalssystemet, vil virke i retning af at overflødiggøre mindretallets kultur, idet en sådan social deltagelse netop vil foregå på flertallets betingelser, dvs. være præget af den dominerende kultur.

Sattes denne proces i gang, må man forudse et frafald fra mindretallet, der 
derved talmæssigt vil kunne blive reduceret til en størrelse, hvor antallet af nationalt blandede ægteskaber vil stige stærkt. Herved forstærkes en anden væsentlig trussel mod mindretallets eksistens, idet det - blandt andet for det tyske mindretal i Danmark - er påvist, at nationalt blandede ægteskaber er en væsentlig faktor til forklaring af nationalitetsskift fra mindretal til flertal. ${ }^{5}$ Det bør understreges, at et mindretals evne til at reproducere sig selv ikke kun afhænger af gruppens absolutte størrelse, men også af dens koncentration i bestemte områder og dermed af mindretalsmedlemmernes mulighed for et indbyrdes socialt samspil.

Dominerende samfundsmæssige processer har $\mathrm{i}$ de seneste 30 år virket $\mathrm{i}$ retning af at fremme disse tendenser. Sammenfattende kan man sige, at de europæiske lande har gennemgået moderniseringsprocesser, der først og fremmest har været karakteriseret af en erhvervsmæssig forskydning fra landbrug til industri og videre til servicevirksomhed. Denne forandring har været forbundet med en betydelig økonomisk vækst målt på landsplan, og den har i de enkelte lande blandt andet bevirket, at den nationale økonomi i højere grad er blevet en enhed, ligesom den har ført til indenlandske befolkningsvandringer. Dette indebar tydeligvis en tendens i retning af en økonomisk assimilation af nationale mindretal - forstået som en øget indviduel deltagelse i det nationale økonomiske system sammen med majoritetsgruppens medlemmer og en svækkelse af mindretallenes befolkningsmæssige koncentration.

Over for disse betragtninger kan det virke paradoksalt, at den samme periode i stigende grad har været karakteriseret ved en genoplivning af den etniske bevidsthed. En gængs forklaring på dette fænomen ser væksten i etnisk bevidsthed som udtryk for det enkelte menneskes psykologiske behov for tilknytning til sociale grupper. Moderniseringsprocesser opløser eller nedbryder netop hidtidige sociale fællesskaber og sammenhænge, og identifikation med den etniske eller nationale gruppe kan derfor være en kompensation herfor. Nationale mindretal af en tilstrækkelig størrelse og med den nødvendige befolkningsmæssige koncentration vil derfor kunne opleve en styrkelse af deres situation parallelt med den samfundsmæssige moderniseringsproces.

Der er således tale om modgående tendenser, hvor resultatet - især på kortere sigt - hverken er klart eller tydeligt. Moderniseringsprocesserne har imidlertid også andre aspekter, der kan bidrage til forklaring af den øgede etniske bevidsthed. Øget politisk aktivitet inden for og/eller med udgangspunkt $i$ etniske og nationale grupper har således vist sig at være en lige så hensigtsmæssig og rationel måde at tilkendegive og varetage gruppeinteresser på som andre former for politisk deltagelse. ${ }^{6}$

To forhold ved moderniseringsprocesser synes i særlig grad at have betyd- 
ning for denne form for politisk interessevaretagelse. Hvis den økonomiske vækst, som følger med moderniseringsprocessen, også kommer et nationalt mindretal til gavn, øges naturligvis mindretallets ressourcer og dermed dets mulighed for at opbygge eller styrke egne organisationer, og herunder også de politiske organisationer. Mindretallets medlemmer vil også individuelt få større ressourcer, der vil kunne omsættes i politisk deltagelse.

Hertil kommer, at dersom et nationalt mindretal udsættes for absolut fremgang, men relativ tilbagegang, fordi andre går endnu mere frem, vil såvel de faktiske muligheder som motivationen til politisk handling være stigende. Selv en absolut tilbagegang for et nationalt mindretal vil kunne resultere i en øget etnisk bevidsthed og politisk aktivitet, nemlig i de tilfælde, hvor ressourcemangel ikke neutraliserer eller forhindrer den ogede motivation.

Der tegner sig på denne baggrund to modsatrettede tendenser for de nationale mindretal i Europa: For det første er en række mindretal på længere sigt udsat for en alvorlig trussel om kulturel assimilation, hvilket er ensbetydende med, at de pågældende mindretal opløses. For det andet er der - måske navnlig på lidt kortere sigt - mulighed for, at mindretallenes sociale selvstyre bliver styrket. Et vigtigt led i denne sidste proces er de nationale mindretals politiske status og dermed deres mulige politiske indflydelse. En tilfredsstillende opfyldelse af mindretallenes ønsker med hensyn til politisk status og indflydelse er under alle omstændigheder en nødvendig betingelse for deres fortsatte eksistens.

De løsningsmuligheder, der i en bestemt situation vil kunne tages i anvendelse, vil ikke kun være betinget af mindretallets oprindelse, størrelse, befolkningsmæssige koncentration og sociale sammensætning, men også af den konkrete nationale sammenhæng.

Inden vi vender os til problematikken omkring mindretallene i Nord- og Sydslesvig, skal der i det følgende gøres et forsøg på at opridse fem forskellige løsningsmodeller for nationale mindretals politiske status.

\section{Nogle løsningsmodeller for nationale mindretals politiske status}

Det vil naturligvis afhænge af øjnene, der ser, om en løsning på et nationalt mindretals politiske status er tilfredsstillende eller ej. Flertalsgruppens og mindretallets interesser kan vel kun siges at være sammenfaldende i det tilfælde, hvor forholdene er utilfredsstillende for mindretallet, og hvor situationen samtidig skaber omkostningsfulde sociale spændinger for majoritetsgruppen. Desværre er en sådan situation ikke usædvanlig, og uenighed om en løsning 
er næsten lige så hyppig. I det mindste fem forskellige modeller kan tages i anvendelse; det drejer sig om:

1. Selvstændighedsmodellen

2. Grænseflytningsmodellen

3. Autonomimodellen

4. Repræsentations- eller ligestillingsmodellen

5. Diskriminations- eller undertrykkelsesmodellen

I forbindelse med en præcisering af disse løsningsmodeller skal vi begrænse os til danske eksempler. Betegnelsen "selvstændighedsmodel« indeholder i sig selv definitionen. Det er den mest vidtgående løsning på et nationalt mindretals politiske problemer. Efter 1. verdenskrig er eksemplerne få i europæisk sammenhæng. Et klart eksempel på modellens anvendelse i en nyere europæisk sammenhæng er ophævelsen af det dansk-islandske rigsfællesskab.

Karakteristisk for modellens anvendelse var for det første, at minoritetssituationen var en følge af dansk kolonipolitik, og for det andet, at Islands selvstændighed i 1918 i realiteten var en løsrivelsesproces, som regering og rigsdag i København ikke kunne gøre meget for at modsætte sig - også af hensyn til den slesvigske situation. Det er væsentligt at understrege, at Islands geografiske placering og størrelse er så unik, at det er vanskeligt at forestille sig modellen taget $i$ anvendelse inden for overskuelig fremtid - bortset måske fra Grønland.

Efter selvstændighedsmodellen følger med hensyn til radikalitet grænseflytningsmodellen. Ønsket om at anvende modellen er kun alt for velkendt $i$ europæisk historie, og i praksis betyder dens anvendelse, at løsningen af ét eller flere mindretals problemer samtidig skaber nye mindretal. I den situation er befolkningsflytninger naturligvis en mulighed. Den er ikke medtaget som en selvstændig løsningsmodel, fordi den ikke har været praktiseret i dansk sammenhæng.

Det danske grænseflytningseksempel er forholdene i Slesvig. Som et resultat af krigen i 1864 blev Slesvig en del af Preussen. Herved var der skabt en løsning for hertugdømmets tysksindede befolkning, men til gengæld var der blevet etableret et meget betydeligt dansk mindretal i denne del af Preussen.

Grænseflytningen i 1920 - Genforeningen - skete efter folkeafstemning i på forhånd fastlagte zoner. Resultatet var ikke den ideelle løsning, men dog formentlig meget nær den bedst mulige løsning. Men brugen af grænseflytning som løsningsmodel havde igen skabt et nyt mindretal - det tyske i Nordslesvig - samtidig med, at en del af det danske mindretal i Sydslesvig var blevet fastholdt $i$ en ny mindretalssituation. I et område som dette kan mindretalspro- 
blemerne ikke løses fuldstændigt ved grænseflytning, selv om de kan reduceres i omfang og intensitet.

Autonomimodellen indebærer, at det nationale mindretal får autonomi altså selvstyre - på et eller flere områder. Dens anvendelse forudsætter vel, at den kan opfattes som legitim også af andre borgere inden for den pågældende større stat; derfor ses denne model især i tilfælde, hvor det pågældende mindretal udgør et faktisk flertal inden for det geografiske område, der har opnået autonomi på nogle bestemte områder.

Færøernes hjemmestyreordning i 1948 og Grønlands i 1979 er de relevante danske eksempler; også uden for Danmark er der en tendens til, at de mindretal, der opnår en form for autonomi, enten bor på øer (Åland, Nordirland) eller på anden måde er forholdsvis geografisk afgrænset (Baskerlandet, det tysktalende mindretal i Østbelgien).

Repræsentations- eller ligestillingsmodellen betyder, at de pågældende mindretal formelt - og reelt - har mulighed for at deltage i den politiske proces på linje med andre, kan danne politiske partier, deltage $\mathrm{i}$ valgene og få mandater $\mathrm{i}$ forhold til gruppens størelse osv. Modellen kan suppleres med positiv særbehandling, som for eksempel fritagelse for spærreregler ved valg eller en valgkredsinddeling, der favoriserer det pågældende mindretal. Det er denne model, der er relevant $i$ forbindelse med det tyske mindretal i Nordslesvig. I nogle tilfælde er modellen ikke anvendelig på det nationale niveau (hvis gruppen er for lille, eller hvis valgretten kun vedrører det lokale niveau). ${ }^{?}$

Diskriminations- eller undertrykkelsesmodellen er naturligvis betegnelsen for den situation, hvor flertallet bruger sin magtposition til at diskriminere mod nationale mindretal. Spørgsmålet om disse mindretals status og politiske udtryksmuligheder illustreres for eksempel med behandlingen af det tyske mindretal umiddelbart efter krigen og med behandlingen af en række fremmedarbejder- og indvandrergrupper. Modellen illustreres dog langt bedre med en række udenlandske eksempler, som der ikke er grund til at gå ind på her.

\section{De slesvigske mindretal}

Pladsen tillader ikke, at der gives en længere redegørelse for udviklingen af de tre mindretal i Slesvig, som er relevante i denne forbindelse, dvs. det tyske i Nordslesvig, det danske i Sydslesvig og de nationale frisere, også i Sydslesvig. Specielt de nationale frisere, det nordfrisiske mindretal, hvis medlemmer især bor i Sydslesvigs vestlige egne, vil kun undtagelsesvist blive behandlet. Selv om der er en stigende interesse for det frisiske sprog, og selv om den 
frisiske nationalbevidsthed er under fortsat udvikling, er der tale om et mindretal af en sådan størrelse, at det antagelig er urealistisk med selvstændige politiske løsningsforsøg.

Det vigtige i denne sammenhæng er understregningen af, at Slesvigs befolkning var dansktalende senest fra det tidspunkt, hvor landsbyerne fik deres nuværende navne, og at der i løbet af det tolvte og begyndelsen af det trettende århundrede etableredes et dansk hertugdømme i området. Man har talt om denne periode - frem til 1241 - som den første af tre i områdets nationale og kulturelle udvikling, ${ }^{8}$ også selv om der fandt en begyndende holstensk kolonisering sted nord for Ejderen allerede i 1100-tallet.

Den næste lange periode - seks århundreder - var først og fremmest karakteriseret ved forsøg på at selvstændiggøre det slesvigske hertugdømme i forhold til den danske krone, af modsatrettede bestræbelser fra den danske konge, af en gradvis indtrængen af holstenske og tyske adelige og godsejere - og bønder - og af en kulturel og sproglig udvikling, der begunstigede tysk sprog og kultur og gradvis førte til en tilbagetrængen af dansk sprog og kultur.

Et væsentligt element i denne udvikling var, at kirkesproget efter Reformationen i en betydelig del af Slesvig blev plattysk, og senere højtysk, som det også var såvel administrationens som overklassens sprog. Overensstemmelsen mellem kirkens - og dermed senere også skolens - sproggrænser og den senere nationalpolitiske udvikling er betydelig; at Slesvig var delt på flere bispedømmer, var antagelig også af en vis betydning.

Udviklingen af nationalitetsideen skabte sammen med den politiske, økonomiske og sociale udvikling i løbet af det nittende århundrede baggrunden for fremkomsten af mere bevidst nationale tilhørsforhold, end der tidligere havde været tale om, i Slesvig og andre steder.

At danskheden var stærkest i den nordlige del og tyskheden (herunder også den slesvig-holstenske orientering) i den sydlige del af Slesvig, er ikke mærkeligt. Sprogforholdene, de kulturelle og politiske orienteringer i det hele taget, til dels også de økonomiske forbindelser, pegede hver sin vej.

Resultatet af krigen i 1864 blev dansk nederlag såvel på det militære som på det diplomatiske felt. Den efterfølgende krig mellem Preussen og Østrig i 1866 førte ved freden i Prag til, at Østrig afstod alle sine rettigheder til Slesvig og Holsten til Preussen; i 1867 blev Slesvig og Holsten en preussisk provins.

Det betød, at de foregående tre-fire årtiers uendeligt komplicerede udvikling var endt med, at de dansksindede i Nordslesvig - hvis bevidste danskhed først var begyndt at udvikle sig i den samme periode - nu var blevet et lille sprogligt og nationalt mindretal $i$ en provins i Preussen.

Historien om, hvorledes de dansksindede i tiden frem til 1920 magtede at fastholde deres nationale tilhørsforhold - trods alle former for chikane og 


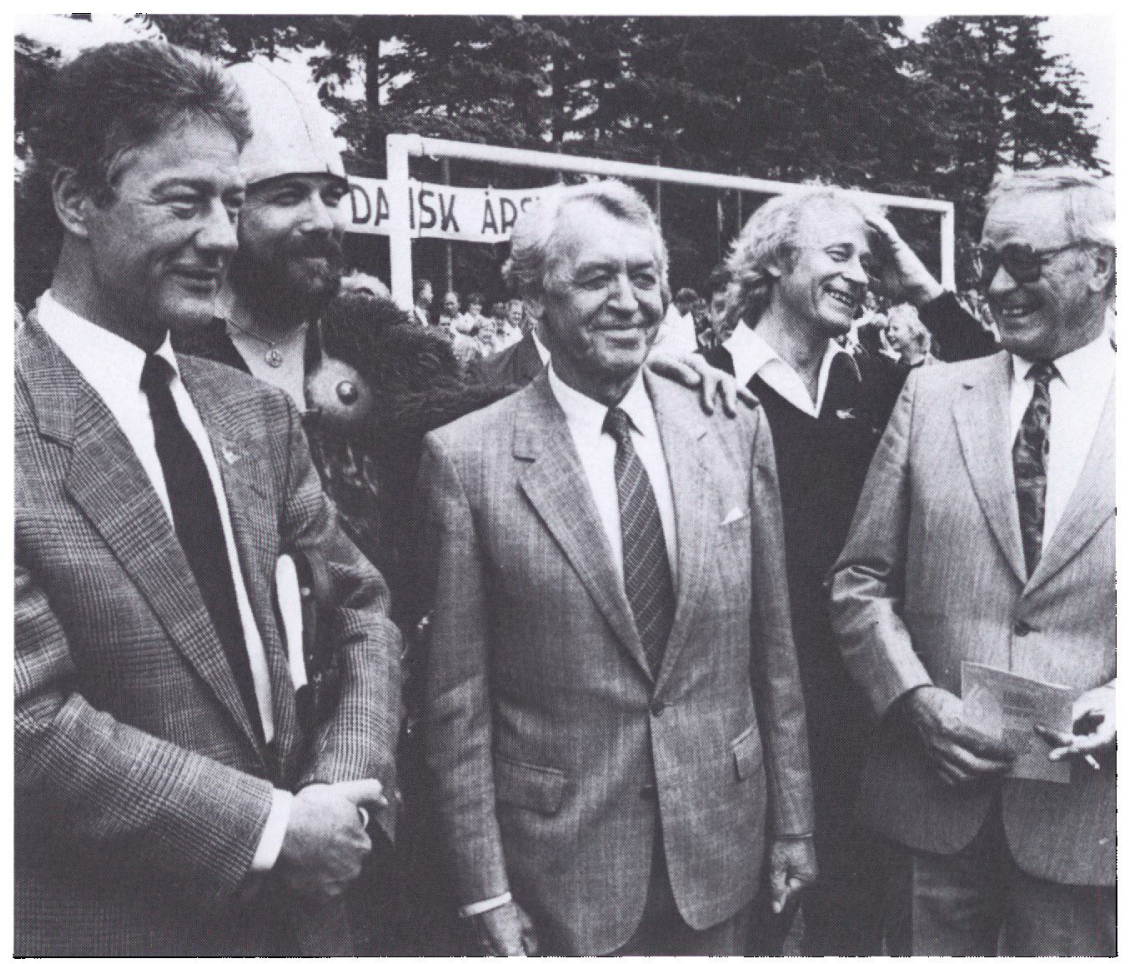

Det danske mindretal, den tyske stat, det danske samfund og den nordiske kultur forenet-i hvert fald på billedet. En Jels-viking er nordisk bindeled mellem Björn Engholm og Erik Ninn-Hansen. Til højre formanden for SSF Heinrich Schultz og generalkonsul Jorgen Peter Hansen.

Får statsminister Poul Schlüter ret, når han spd̊r om nationalstaten og nationalfolelsens bortdoen, eller havde Folketingets formand, Erik Ninn-Hansen, ret, da han under de danske drsmoder $i$ begyndelsen af juni 1989 sagde pd modet $i$ Flensborg, at "Danmark stadig skal vare centrum $i$ vort verdensbilledew? En situation fra de danske drsmoder i Flensborg 1989 er her indfanget af Michael Mauter, Flensborg Avis. Dansk Centralbibliotek for Sydslesvig.

fortyskningsforsøg fra de preussiske myndigheder og deres tysksindede og slesvig-holstenske medborgere - er velkendt og skal ikke fortælles her. Artikel $\mathrm{V}$ i Prag-freden indeholdt en passus om folkeafstemning om det fremtidige statslige tilhørsforhold $\mathrm{i}$ »de nordlige distrikter« af Slesvig. Formuleringen bidrog til at holde håbet $\mathrm{i}$ live, og da den blev ophævet $\mathrm{i} 1878$, var den nationale identitet så veletableret, at også dette slag kunne overvindes. Hertil bidrog opbakningen fra brede kredse i Danmark.

Som led i Versailles-forhandlingerne efter 1 . verdenskrig blev det besluttet at afholde en folkeafstemning, der kunne bidrage til at afgøre, hvor stor en del 
af Slesvig der skulle »genforenes« med Danmark, som det hedder i den danske terminologi.

Både i Danmark og blandt de dansksindede i Slesvig stod to linjer over for hinanden, en mere moderat, der kun ville have de dele af Slesvig, hvor der var dansk flertal, og som derfor måtte antages at skabe færrest problemer $\mathrm{i}$ en ukendt fremtid, når Tyskland måske igen ville have fået stormagtstatus, og en mere "maksimalistisk «, der ville have så meget som muligt af det Slesvig, der fra gammel tid - og trods alle historiske komplikationer - var dansk.

I begyndelsen af 1920 gennemførtes to folkeafstemninger. I 1. zone, nord for den nuværende dansk-tyske grænse, var der er klart flertal for Danmark af de afgivne stemmer, $75.400 \mathrm{mod} 25.300 . \mathrm{Og}$ i 2 . zone, som stemte en månedstid senere, var billedet lige så klart, men med modsat fortegn: 51.700 for Tyskland, 12.800 for Danmark. Syd for den nye grænse var der ingen kommuner, der havde mere end 33 pct. stemmer for Danmark, medens der i Nordslesvig var nogle - både blandt købstæderne og landkommunerne - der havde flertal for Tyskland. Det var specielt tilfældet umiddelbart nord for den nuværende grænse. Den konkrete betydning dels af den kommunevise afstemning i 2. zone, dels af preussiske embedsmænds påvirkning af lokalbefolkningen er $i$ øvrigt vanskelig at gøre op.

Genforeningen etablerede den nuværende situation i området, idet grænsen af 1920 ikke er blevet ændret siden, hverken i 1930'erne eller i slutningen af 1940'erne, hvor det nazistiske Tysklands totale nederlag skabte en situation, der ikke var uden lighedspunkter med den efter 1. verdenskrig. I debatten om, hvad der da skulle ske, kan man også konstatere de samme to linjer; og igen sejrede den mere moderate.

Situationen har altså været den, at der siden 1920 har været et tysksindet mindretal i Danmark, samtidig med, at der har været et dansksindet mindretal i Tyskland, i Sydslesvig.

Det er i øvrigt vigtigt at være opmærksom på det komplicerede forhold mellem sindelag og sprog i det slesvigske område. Syd for grænsen kan man ikke ud fra familie- eller hjemmesproget sige noget absolut om dansk- eller tysksindethed. Sproget er altså ikke anvendeligt som enkeltstående kriterium på det nationale sindelag. Det samme er $\mathrm{i}$ betydelig udstrækning tilfældet blandt det tyske mindretals medlemmer i Danmark. For det danske flertal er der dog en til vished grænsende sandsynlighed for, at de har dansk hjemmesprog.

Det betyder, at man ikke kan beskæftige sig med de slesvigske mindretal som sproglige mindretal, selv om der naturligvis er sammenhæng mellem sindelag og sprog. Det skyldes blandt andet, at brugen af den pågældende kulturs sprog er en del af mindretallenes (og af flertallenes) ideologi; selvopfat- 
telsen bygger blandt andet på sprog - dansk, henholdsvis tysk - som en integreret og væsentlig del af den pågældende befolkningsgruppes samlede kultur. Virkeligheden var - og er - imidlertid en anden, således som alle med kendskab til forholdene i grænselandet ved. Her skal kun mindes om, at den overvejende del af de familier, der har børn i det danske skolevæsen i Sydslesvig, har tysk hjemmesprog. ${ }^{9}$ Brugen af tysk i det danske mindretalsarbejde er derfor et forhold, der ofte giver anledning til diskussion.

Begge mindretallene har talt om, at de blev mefterladt « $i$ det nuværende værtsland i 1920. Med dette udtryk er en del af deres sindsstemning naturligvis kommet til udtryk, samtidig med, at ønsket om revision satte sit præg på deres politiske bestræbelser.

En grænsedragning, som bevidst prøver at tage hensyn til befolkningens nationale tilhørsforhold, kan ikke gennemføres i et område som det slesvigske, uden at der "efterlades" nogen af den ene nationalitet i den anden stat. Det er en konsekvens af den historiske udvikling, hvor en lang række faktorer har blandet sig, og hvor et af resultaterne er blevet, at bosættelsen endnu i dag er blandet. Det gælder i særdeleshed, jo tattere man kommer på det sted, hvor grænsen mellem de to lande trækkes.

Hertil kommer, at der er en intim forbindelse mellem størrelsen på de to mindretal: Jo mindre et dansk mindretal, man fra dansk side ville efterlade syd for den nye grænse, jo større et tysk mindretal ville man automatisk få nord for grænsen. Og omvendt.

Det tyske mindretal i Nordslesvig stod i 1920 til dels i den samme situation som det danske mindretal i 1867 . Gruppens sociale, kulturelle og organisatoriske liv havde $i$ et vist omfang været båret af de embedsmænd, der på grund af det statspolitiske skifte nu måtte rejse bort, og det betød, at man $i$ et vist omfang måtte starte på bar bund. Og selv om det indgik i det tyske mindretals politiske ideologi, at grænsedragningen måtte revideres, så var der - på grund af den måde, Genforeningen var foregået på - både formelt og reelt langt mindre at bygge revisionistiske forhåbninger på, end der $\mathrm{i}$ sin tid havde været for det danske mindretal i Preussen.

Hertil kom, at hovedparten af de danske politikere og embedsmænd var enige om udformningen af en dansk mindretalspolitik - noget, man ikke selv havde aktuelle erfaringer med, men hvor man jo blandt andet kunne se på virkningerne af den preussiske politik og på de erfaringer, som det danske mindretal havde gjort i Preussen før 1920. Et af hovedmålene måtte være at undgå alt, der ville kunne skabe konflikter eller indblandingsmuligheder for et kommende stærkt Tyskland - den unge Weimar-republik var der jo ikke meget at frygte fra. 
Derfor blev hovedlinjen i den danske politik at undgå en form for mindretalsaftale eller -garanti med Tyskland, uanset de fordele, det eventuelt kunne have medført for det danske mindretal syd for grænsen. Linjen blev, at den almindelige liberale danske lovgivning på skole- og kirkeområdet sammen med grundlovens sikring af de almindelige frihedsrettigheder $\mathrm{i}$ hovedsagen måtte være nok til at sikre den anstændige behandling af det tyske mindretal, som man var enige om. Hertil hørte selvfølgelig også retten til i en række sammenhænge at benytte sig af tysk. ${ }^{10}$

Den danske politik over for mindretallet kan altså karakteriseres ved

(1) ønsket om at umuliggøre tysk indblanding i forholdet mellem den danske stat og det tyske mindretal,

(2) at mindretallets medlemmer skulle have frie hænder til at indrette sig inden for det danske samfund, hvis almindelige lovgivning i alt væsentligt gav passende rammer for det,

(3) dublering af de kulturelle institutioner (skoler, kirkelig betjening osv.), hvor det var befolkningsmæssigt begrundet,

(4) afstandtagen fra alle former for nationale »katastre«, dvs. fortegnelser over, om den enkelte borger var tysk- eller dansksindet, også i form af spørgsmål i folketællinger og lignende om sprogbrug, og

(5) sikring af det tyske mindretals deltagelse i det almindelige politiske liv både lokalt og nationalt; med henblik på det sidste blev der blandt andet lavet en form for positiv valggeometri, der sikrede, at mindretallet med meget stor sandsynlighed kunne få et folketingsmandat. Derfor var mindretallet - i første omgang - repræsenteret i Folketinget 1920-43.

(6) Endelig kan man pege på gensidigheds-princippet, som har ligget som en mere eller mindre udtalt bestræbelse bag den danske politik, men som man, jfr. (1), ikke ville give en juridisk bindende form. Med Bonn-Københavnerklæringerne i 1955 og den senere udvikling, som disse erklæringers moralske pression bidrog til, er dette led i udformningen af mindretalspolitikken blevet tydeligere end før.

Disse elementer har været centrale i den danske mindretalspolitik siden 1920.

I forbindelse med gennemførelse af denne liberale og hensyntagende mindretalspolitik - hvis sandsynligvis positive virkninger på en fremtidig assimilation, en række af aktørerne var helt opmærksomme på - er det værd at hæfte sig ved, at det tyske mindretal reelt ikke blev inddraget $\mathrm{i}$ forhandlingerne. Mindretallets egen stilling før og under Genforeningen er naturligvis af betydning i denne forbindelse, men det er også åbenlyst, at der ikke fra dansk og sønderjysk side var noget egentligt ønske om at inddrage mindretallet - så langt rakte liberaliteten ikke! 


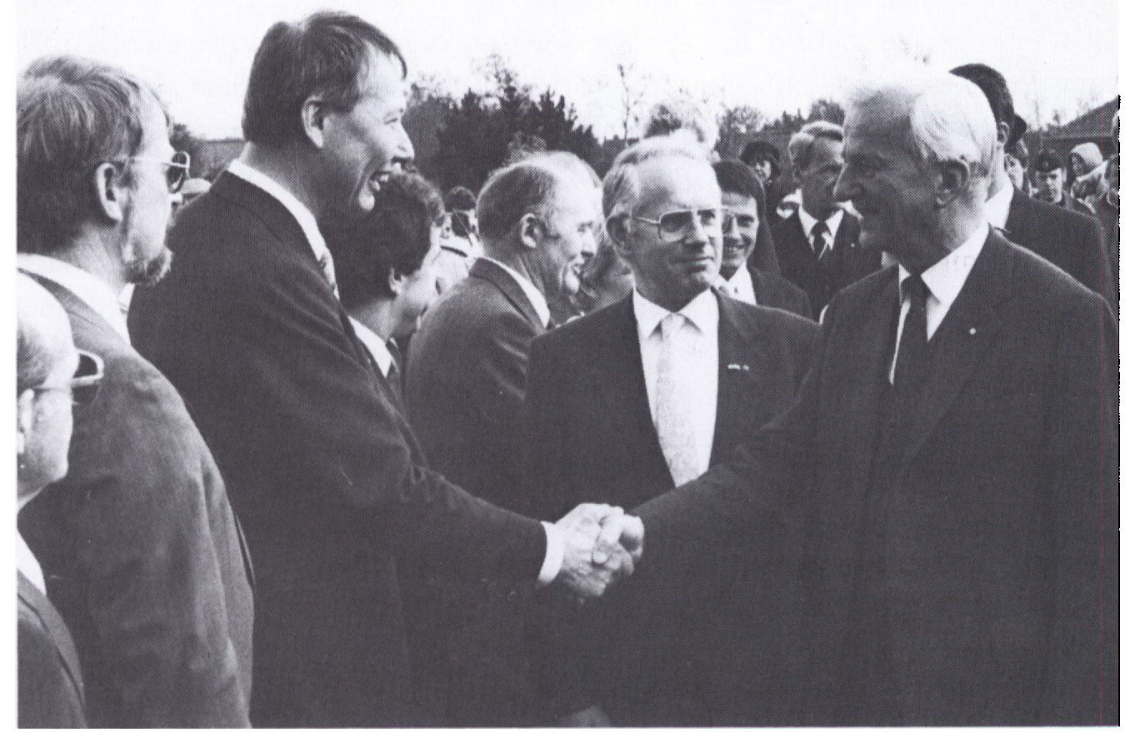

Samhorigheden med den falles nationale kultur bekraftes: Forbundsprasident Richard von Weizsäcker besogte under sit besøg i Danmark i foråret 1989 også det tyske mindretal og hilser her på mindretallets generalsekretar Peter Iver Johannsen. En sådan begivenhed styrker fallesskabsfolelsen i et mindretal, ligesom den bidrager til at markere, at man er forskellig fra fiertalsgruppen. I midten ses formanden for Bund Deutscher Nordschleswiger Gerhard Schmidt. Foto Michael Mauter. Dansk Centralbibliotek for Sydslesvig.

Hvor stort var det tyske mindretal i Danmark efter 1920? Som næunt ovenfor blev der ved afstemningen i 1. zone afgivet 25.300 stemmer for Tyskland, nogle af disse af tilrejsende, andre af vælgere i alderen 20-24, som ikke havde valgret ved folketingsvalg, hvad der skal huskes ved sammenligning med senere valg. Ved de første to folketingsvalg blev der afgivet knap 8.000 stemmer på det nydannede Slesvigsk Parti, svarende til små 10 pct. af alle stemmer i Nordslesvig.

Derefter steg stemmetallet til omkring 10.000 (11-12 pct.), i 1935 blev det 12.600 (13 pct.) og i 1939, hvor henvisningerne til forholdene syd for grænsen var mest intense, 15.000 stemmer, svarende til knap 15 pct. af de afgivne stemmer. Da det tyske mindretal ikke boede jæunt fordelt over landsdelen, men havde sine stærkeste områder $i$ nogle af kommunerne tæt ved grænsen, kan der være grund til at nævne, at i disse mindre områder lå Slesvigske Partis stemmeandel ved de to sidste folketingsvalg før krigen på 35-40 pct.

Erfaringerne med det tyske mindretals nazificering og hele adfærd under 2. verdenskrig og den tyske besættelse betød nok et afbræk på visse punkter $\mathrm{i}$ 
den danske mindretalspolitik i slutningen af 1940'erne og i begyndelsen af 1950 'erne; men siden midten af 1950 'erne har de ovennævnte elementer igen været centrale, og de anfægtes ikke på nogen måde fra flertallets side.

Hertil bidrager især to ting: Den første er, at det tyske mindretal efter 2. verdenskrig selv har gennemgået en erkendelsesmæssig proces, hvorved man er kommet frem til at acceptere grænsen. Målsætningen for mindretallet er nu at fastholde - eventuelt at videreudvikle - sin tyske kultur og identitet, men inden for den danske stats grænser; der er altså tale om en anden overordnet målsætning end tidligere.

Den anden væsentlige faktor er, at mindretallet er blevet mindre, dvs. at den assimilationsproces, som nogle allerede tænkte på $i$ årene 1918-20, tilsyneladende skrider fremad på en måde, der begynder at kunne ses mere direkte end tidligere.

Præcise og nøjagtige opgørelser af et sindelagsmindretals størrelse er vanskelige at foretage - og heller ikke så vigtige. Der findes ingen enkelt indikator, som kan bruges alene - og brugen af forskellige, såsom stemmetal, læsning af mindretallets tysksprogede avis eller tysk kirkegang, giver forskellige resultater.

Man kan dog se på den relative udvikling, idet et fald i for eksempel stemmetallet naturligvis ikke kan tolkes på anden måde end som et fald $\mathrm{i}$ mindretallets styrke sammenlignet med tidligere.

Med »den relative udvikling« tænkes her ikke på, hvor stor for eksempel procenten af stemmer på Slesvigsk Parti er. I en tid, hvor mindretallets aldersstruktur på grund af forholdsvis mange ældre afviger fra flertallets, og hvor indvandring nordfra til Nordslesvig som led i den almindelige regionale befolkningsomflytning er en styrkelse af flertallet, vil det tyske mindretals andel af den samlede befolkning i Nordslesvig - og Slesvigsk Partis andel af alle stemmer - allerede af disse grunde vise en svagt nedadgående tendens. Det har da også været tilfældet siden begyndelsen af 1950'erne, som er det naturlige udgangspunkt.

Ved valget i september 1953 fik Slesvigsk Parti knap otte pct. af stemmerne i Nordslesvig; nu ville partiet, hvis det stillede op, antagelig få mindre end tre pct. Folketingsmandatet gik tabt i 1964, ikke på grund af diskrimination eller modarbejdelse fra flertallets side, men fordi stemmetallet var blevet for lille til at sikre et af de direkte kredsmandater, som er den nemmeste og sikreste måde, hvorpå et regionalt afgrænset parti kan vinde repræsentation i Danmark.

Siden 1971 har partiet imidlertid ikke stillet op selvstændigt, og efter et mellemspil med opstilling på et af de andre partiers liste er det tyske mindretals rolle nu udspillet i relation til Folketinget.

På det lokale plan stiller tingene sig anderledes. Dels har mindretallet indtil nu haft styrke til at fastholde et mandat i amtsrådet (tidligere to), dels har det 


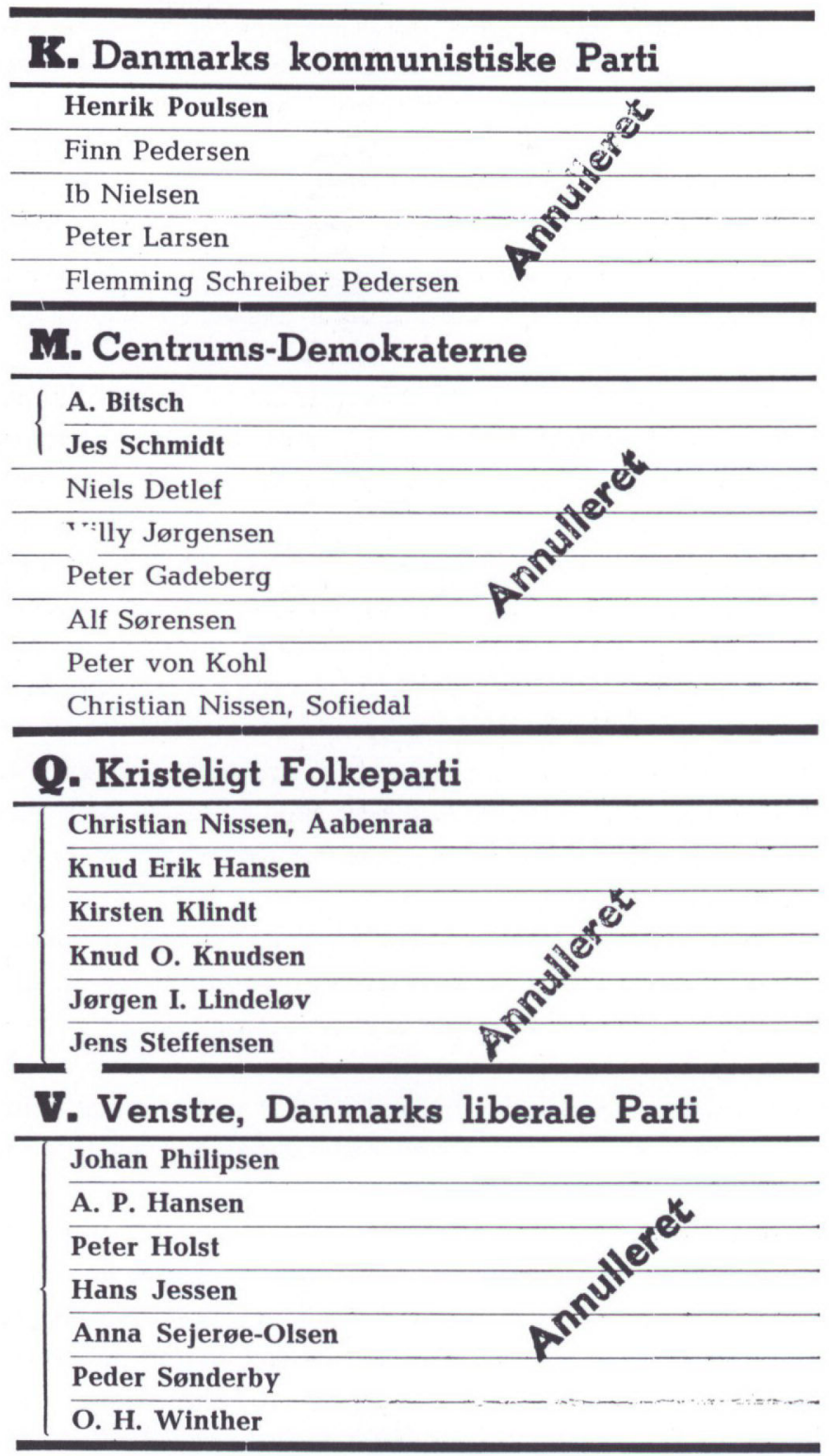

Dette udsnit af en stemmeseddel fra folketingsvalget $i 1973$ viser en ganske interessant lesning pd et nationalt mindretals politiske reprasentationsproblemer: I 1973 tilbod Erhard Jacobsen det tyske mindretal (Jes Schmidt) plads pa det nystiftede $C D$ 's liste $i$ den sonderjyske amtskreds. Det kunne både skaffe CD flere stemmer og understrege, at partiet mente noget med sin afstandtagen fra de traditionelle ideologier. Denne losning er dog sà speciel, at den ikke kan kaldes en egentlig losningsmodel. Stemmesedlen er hentet i Aabenraa kommunes arkiv. 
i et par af købstæderne og i nogle af landkommunerne en styrke, der gør det naturligt at stille op - ikke bare for at manifestere sin tilstedeværelse, men også for at få valgt repræsentanter $\mathrm{i}$ kommunalbestyrelsen.

Når flertallet vokser, er det derfor nødvendigt at se på mindretallets absolutte styrke for at vurdere, om den ændrer sig fra valg til valg. Det er i denne forstand, at man skal se på den relative udvikling. Her har der været en større grad af stabilitet, idet mindretallet ved amtsrådsvalgene 1974-1981 fik 6.3006.500 stemmer og lidt mindre ved kommunalvalgene, fordi man som nævnt ikke stiller op i nogle af de mest udsigtsløse kommuner.

Ved amtsrådsvalget i 1985 mistede man imidlertid næsten 700 stemmer i forhold til valget i 1981; det er en tilbagegang på 11 pct. Derfor knytter der sig betydelig interesse til valget $\mathrm{i}$ november 1989 . Var der særlige forhold $\mathrm{i}$ 1985, som kan forklare det dårlige resultat, eller er der tale om et markant skridt $\mathrm{i}$ en udvikling, som har været $\mathrm{i}$ gang i mange år, men som tidligere er gået langsomt, og som først nu er kommet til et mere kritisk punkt?

Hvorledes kan man skønne over forholdet mellem mindretallets størrelse og valgtal, der er påvirket af mange forskellige faktorer? En samlet hensyntagen til eventuelle forskelle $\mathrm{i}$ valgdeltagelse - på grund af forskelle i såvel motivation som alderssammensætning - gør det rimeligt at sige, at de slesvigske mindretals stemmetal i vore dage nok skal multipliceres med en faktor på mellem $1.5 \mathrm{og}$ 1.75 for at give et brugeligt billede. For det tyske mindretal giver det altså en samlet tilslutning mellem $9.000 \mathrm{og} 11.000$.

Det er mindre end de 15.000 , som mindretallet selv plejer at hævde, og kun halvdelen af de 20.000 som Den europæiske organisation for de mindre talte Sprog har brugt som grundlag for sin argumentation."

Det danske mindretal i Sydslesvig har siden 1920 på en række områder haft vanskeligere - på nogle meget vanskeligere - vilkår end det tyske mindretal nord for grænsen.

For det første var det danske mindretal i 1920 mindre - for eksempel bedømt ud fra stemmetal - og det omgivende samfund, dvs. det flertal, man stod overfor, var "større«. For det andet fortsatte lokale instanser en politik over for mindretallet, som i hvert fald ikke var præget af den mindretalspositive ånd, som i mellemkrigstiden ellers prægede forholdene mange steder. Dette viste sig på en række områder, blandt andet på skoleområdet, hvor forholdene først efter midten af 1920'erne blev lidt bedre, blandt andet med skoleanordningen af 31 . december 1928, der eksplicit indførte sindelagskriteriet og også fjernede andre begrænsninger.

Hitlertidens generelle usikkerhed og dens elimination af retsstaten skabte også vanskeligheder for det danske mindretal, selv om forholdene ikke blev 
så vanskelige, som de kunne være blevet. Især efter 1936 forsøgte man dog fra tysk side på forskellig vis at tvinge dem, man opfattede som "uægte« mindretalsmedlemmer, til at forlade mindretallet. ${ }^{12}$

Også i denne sammenhæng er det vigtigt at være opmærksom på, hvorledes det komplicerede forhold mellem nationalt sindelag og sprog bidrog til kompleksiteten i det samlede slesvigske mindretalsbillede, således som det blev fremhævet ovenfor.

Skolen er en afgørende faktor i formidlingen af den kulturelle - og dermed også den sproglige - arv, og derfor er der altid blevet lagt megen vægt på skoleforholdene. Sådan var det i mellemkrigstiden, og sådan var det $i$ den første efterkrigstid, hvor den eksplosionsagtige tilgang til det danske sindelagsmindretal førte til, at der opstod et stort behov for sprogundervisning, både hos børn og voksne. Forståelsen for skolens betydning er stadig stor.

Væksten i det danske mindretal efter Tysklands sammenbrud i 1945 er interessant og vigtig under mange synsvinkler. Hvad var det for faktorer, der fik tilslutningen til det lille overlevende mindretal til at stige til det tyvedobbelte eller mere? Hvad var det derefter for faktorer, der fik denne konjunkturelle udvikling til at vende i slutningen af 1948 ? Og uanset det store fald gennem de næste to årtier, hvad er så forklaringen på, at mange er holdt ved, således at mindretallet stadig er klart større end i mellemkrigstiden? Disse spørgsmål skal ikke forsøges besvaret her; de stilles kun for at understrege, at forklaringen på den samlede udvikling er kompliceret.

Den kulturelle forening SSF (Sydslesvigsk Forening) har nu knap 19.000 medlemmer, og stemmetallene ved de to landdagsvalg i september $1987 \mathrm{og}$ maj 1988 var henholdsvis 23.300 og 25.500. Væksten i stemmetal er altså klar nok, også hvis man ser på de 21.800 stemmer, SSV (Sydslesvigsk Vælgerforening) fik ved landdagsvalget $i 1983$.

Ganske som i forbindelse med det tyske mindretal i Danmark skal man imidlertid være varsom med at bruge stemmetallene som grundlag for slutninger om mindretallets størrelse. Det gælder især, når der er et - om end meget langsomt - fald i SSF's medlemstal, samtidig med at der som nævnt kan konstateres stigning i tilslutningen ved landdagsvalgene (både absolut og relativt) og tilnærmelse mellem vælgertallene ved kommunalvalgene og landdagsvalgene.

Det tyder på, at stigningen i SSV's tilslutning kommer fra kredse, der ikke kan regnes med til det dansksindede mindretal. Der er altså tale om en tilslutning til et regionalt parti, hvis landdagsrepræsentant respekteres af mange - måske i en form for fravalg af de øvrige partier. Det har givetvis været tilfældet ved valget i maj 1988, efter Barschel-skandalen. Faldet i SSV's stemmetal i de tre Flensborgvalgkredse (altså det stærkest danske område) og den 
tilsvarende større stigning i de øvrige sydslesvigske valgkredse tyder i hvert fald på, at billedet er kompliceret og kræver detaljerede analyser, før en mere endelig tydning kan præsenteres. Hertil kommer, at den øgede tilgang til SDU (Sydslesvigs danske Ungdomsforeninger) og den beskedne vækst i den procentdel af børnene, der søger til de danske skoler, ikke uden videre kan tolkes som en entydig vækst - eventuelt fremtidig - for mindretallet.

Under alle omstændigheder er det svært $i$ det foreliggende materiale at se noget holdepunkt for, at det danske mindretal stadig skulle omfatte så mange som 50.000. Tallet er ikke $i$ sig selv så vigtigt, men det kan alligevel være hensigtsmæssigt at forsøge at skønne det mere præcist.

Brug af de ovennæunte multiplikationsfaktorer, hensyntagen til mindretallets aldersstruktur, samt erkendelse af, at SSV også er et reelt alternativ for tysksindede sydslesvigere, fører til et tal i størrelsesordenen 35.000-40.000. En sådan usikkerhed viser dels, at opgørelsen er vanskelig, dels at det ikke er vigtigt at kende det mere præcist end her. På baggrund af såvel den økonomiske udvikling i Sydslesvig - relativt til resten af Vesttyskland - som overvejelserne $i$ afsnit 1 er det interessant, at den talmæssige udvikling har været som den har.

Der kan måske være grund til at nævne, at da der ikke er gennemført større videnskabelige undersøgelser af det danske mindretal, er den systematiske viden herom beskeden. Kilden til viden om mindretallet er derfor dels mindretallets egne organisationer, ${ }^{13}$ dels kyndige iagttagere. For mange af dem er der ikke tvivl om, at den aktuelle stabilitet/fremgang for mindretallet $i$ høj grad har forbindelse med den vanskelige økonomiske og sociale udvikling - blandt andet karakteriseret ved en betydelig arbejdsløshed - $\mathrm{i}$ det periferi-område, som Sydslesvig er både på delstats- og forbundsniveau.

Tilslutningen til SSF og SSV rummer altså også et vigtigt regionalpolitisk element. Opfattelsen af SSV som en alternativ og realistisk artikulationskanal har utvivlsomt også forbindelse med såvel det stive tyske partisystem som den høje spærreregel.

\section{Faktiske løsninger på de slesvigske mindretals politiske status}

Erfaringerne i Preussen havde lært de danske sønderjyder, at det kunne være nyttigt for begge parter, at der var kontakt mellem mindretallet og det politiske systems forskellige niveauer. Der var derfor ingen dișkussion om, hvorvidt det nye tyske mindretal i Danmark efter 1920 skulle have mulighed for at blive repræsenteret på alle politiske niveauer i forhold til sin stemmemæssige styrke, 
Jahrelang regierten sie das Land mit absoluter Mehrheit.

Niemand konnte ihre Entscheidungen ändern.

\section{Bis Karl Otto Meyer}

und seine Leute sich vornahmen, dem Parlament die Macht zurückzugeben.
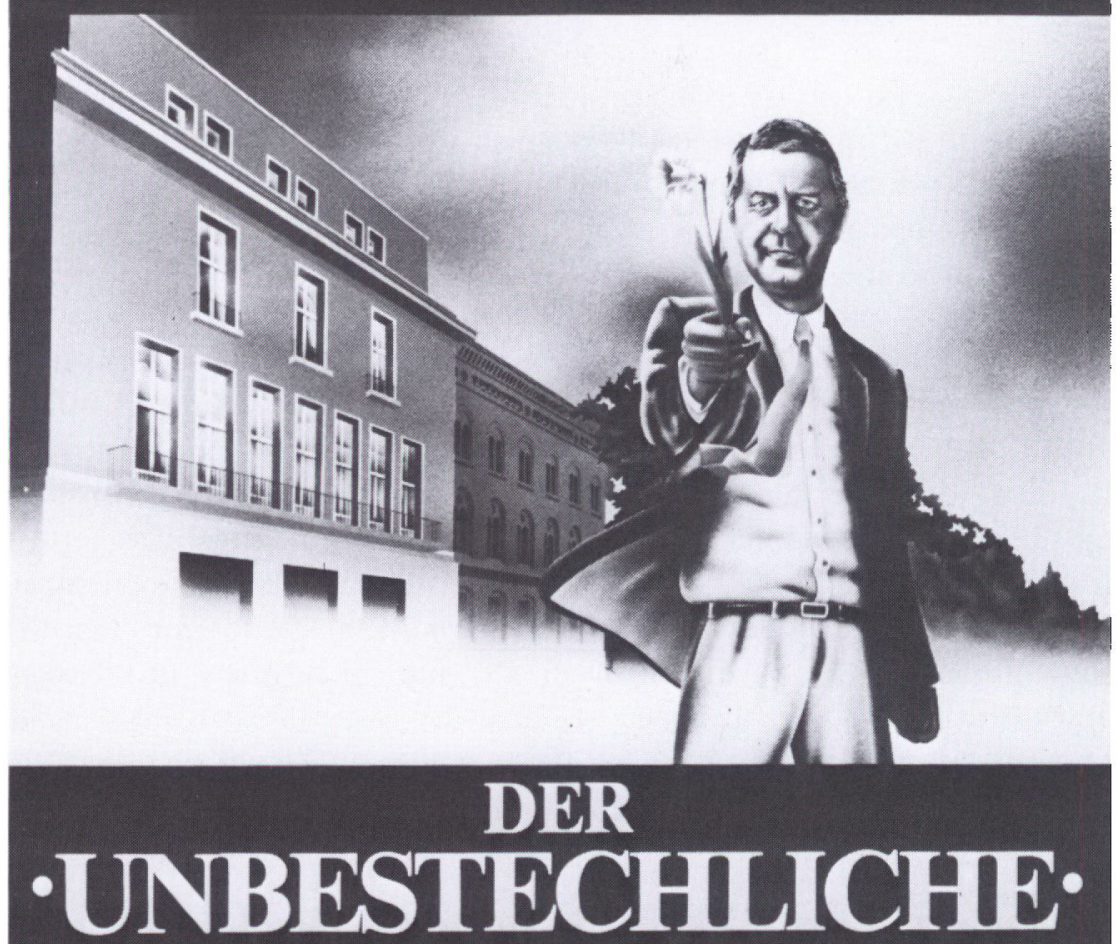

Jugend im SSW präsentiert eine SSW-Produktion

in der Hauptrolle: Karl Otto Meyer

Idee: Jugend im SSW Realisation: Design Team Nord

Verantwortlich: SSW, Landesverband

ein Plakat im Verleih der

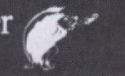

LANDESPREMIIERE AM 8. MAI

Denne plakat fra SSV's ungdomsafdeling fra landdagsvalget i maj 1988 er pd tysk. Det betyder naturligvis ikke, at det danske sindelag eller kampen for det danske sprog er blevet opgivet. Plakaten signalerer nemlig meget klart opposition til tysk kultur, og den peger derved netop pd de nationale forskelle. Den tyske tekst og den anderledes stil betyder ogsd, at den appellerede til tyske valgere, der $i$ den konkrete situation onskede at opponere mod Barschel-skandalen og begivenhederne $i$ dennes kolvand. Dansk Centralbibliotek for Sydslesvig. 
og sådan har det da også været siden (bortset fra de særlige forhold under og efter krigen).

Da mindretallets parti efter 1964 ikke længere var repræsenteret i Folketinget, tog regeringen derfor initiativ til det såkaldte "Kontaktudvalg«, hvor regeringen, Folketinget og mindretallet har mulighed for at udveksle synspunkter og få afklaret forhold af betydning for mindretallet - og derigennem også for flertallet.

I sin frustration over det mistede folketingsmandat argumenterede mindretallet siden midten af 1960 'erne imod den danske valglovs spærreregel, idet man hævdede, at det var urimeligt, at man som et nationalt mindretal - og med mindre end en halv pet. af alle stemmer på landsplan - skulle opfylde et krav om to pct. af stemmerne for at få del i tillægsmandaterne. Forbindelsen til den tyske ophævelse af fem pct.-grænsen for nationale mindretal i 1955 er åbenbar, men argumentationen var uholdbar, og den blev da heller ikke accepteret af danske politikere eller myndigheder.

Et responsum om disse forhold ${ }^{14}$ bidrog til en bedre forståelse af forholdene på valglovsområdet, og angrebene på to pct.-reglen hørte op. Stort set samtidig voksede der blandt danske politikere en forståelse frem for, at man måtte sikre en bedre - og i hvert fald mere permanent - forbindelse til regering, Folketing og administration, end det var muligt gennem Kontaktudvalget. Det førte forsinket af folketingsvalget i 1981 og regeringsskiftet i 1982 - til oprettelsen af Det tyske mindretals Sekretariat i København i 1983. Det har siden fungeret som informations- og påvirkningskanal. Den præcise betydning er vanskelig at vurdere, men det forekommer, at det under en række synsvinkler - og sammen med Kontaktudvalget - har fungeret efter sin hensigt.

Modellen for løsningen af de forskellige mindretalsproblemer er grundlæggende den samme i Sydslesvig som i Nordslesvig. Inden for de galdende rammer - forfatningen, valglovgivningen osv. - må mindretallene sikre sig repræsentation og politisk indflydelse $\mathrm{i}$ forhold til deres størrelse (som opgjort ved stemmetallene på mindretallets politiske parti) og på de relevante politiske niveauer. Derefter må de så indgå i den almindelige politiske proces. Accepten i Slesvig-Holsten af denne grundlæggende model har dog ikke altid været lige udtalt hos alle flertallets politiske aktører, og der har tidligere været giort forsøg på at mindske mindretallets muligheder for en forholdsmæssig repræsentation.

Forskelle mellem de to staters valglovspolitik i relation til de to mindretal kan altså konstateres, og vi har $\mathrm{i}$ anden sammenhæng vist, hvorledes disse forskelle lader sig forklare med udgangspunkt $\mathrm{i}$ forskelle i målsætninger og ressourcer. ${ }^{15}$ Men grundlæggende er der trods alt tale om den samme løsningsmodel, repræsentations- eller ligestillingsmodellen. 
Det er ikke muligt - og i denne sammenhæng heller ikke nødvendigt - at komme ind på de tilfælde, hvor der i det slesvig-holstenske politiske miljø har været tøven over for denne løsningsmodel - som regel i form af forsøg på at mindske mindretallets muligheder ved at skræmme medlemmerne væk eller ved at etablere barrierer, som var åbenlyst urimelige. De mest åbenbare eksempler herpå er omlægninger af valgkredse til ugunst for mindretallet og forhøjelsen i 1951 af spærrereglen til 7.5 pct. Forfatningsdomstolen i Karlsruhe kendte dog senere denne valglovsændring forfatningsstridig.

Parallelliteten fremgår også af, at der også i Tyskland har været forskellige former for kontaktudvalg - både i Kiel og Bonn - i perioder, hvor mindretallet ikke har været repræsenteret. Den form, hvorunder disse udvalg er blevet etableret, er i denne sammenhæng mindre vigtig.

Det giver derfor god mening at understrege ensartetheden mellem de grundlæggende løsningsmodeller, der er blevet taget $i$ anvendelse til regulering af de politiske forhold for de to slesvigske mindretal.

De nationale frisere i Sydslesvig har principielt de samme muligheder, selv om deres beskedne antal betyder, at der kun er mulighed for at anvende løsningsmodellen i samarbejde med SSV.

Betoningen af ensartetheden med hensyn til løsningsmodel gælder i særdeleshed, når der sammenlignes med de forskellige modeller, der generelt er blevet bragt $i$ anvendelse $i$ relation til mindretal andre steder $i$ Europa.

Derfor er der ikke noget mærkeligt $i$, at der inden for de forskellige rammer, som udgøres af de samfundsmæssige systemer i Danmark og Slesvig-Holsten, har kunnet konstateres en række ensartede resultater og konsekvenser af anvendelsen af disse løsningsmodeller, alle de mange forskelligheder ufortalt.

Mindretallene er altså grundlæggende i samme situation, også selv om man fra dansk side nok vil hævde, at man har fort en mere liberal mindretalspolitik og har været mere konsekvent $\mathrm{i}$ sin anvendelse af løsningsmodellen, end tilfældet har været syd for grænsen.

Ensartetheden med hensyn til politisk løsningsmodel er - som det er fremgået - resultatet af en lang udvikling. Der er imidlertid ingen grund til at antage, at denne udvikling forst og fremmest skyldes ideelle overvejelser hos de to flertalsbefolkninger. Tværtimod taler meget for, at væsentlige træk i mindretalspolitikken skal forklares ud fra de to flertals egeninteresse. Vi har således tidligere påvist, at det ud fra denne opfattelse er muligt at give en tilfredsstillende forklaring på udviklingen og specielt på henholdsvis dansk og tysk valglovgivning over for de respektive mindretal. ${ }^{16}$

Således findes der $\mathrm{i}$ den tyske politik over for det danske mindretal før 2. verdenskrig - og for eksempel også $i$ begyndelsen af 1950'erne - væsentlige 
elementer af diskriminationspolitik. Det er i denne henseende mindre væsentligt, om diskriminationspolitikken havde som mål at sikre assimilation af hele det danske mindretal eller kun de mere marginale ("uægte«) dele af det.

Det faktiske fravær af sådanne elementer $\mathrm{i}$ den danske politik over for det tyske mindretal forklares i denne sammenhæng med, at det af sikkerhedspolitiske grunde ville være for omkostnings- og risikofuldt for Danmark på grund af det grundlæggende asymmetriske forhold mellem de to lande. Efter krigen blev disse grunde naturligt nok ikke tillagt samme vægt, og derfor ser vi i en kort periode i slutningen af 1940'erne også elementer af diskriminationsog undertrykkelsespolitik i Danmark. At denne politik blev forsvaret med mindretallets adfærd under besættelsen ændrer ikke noget ved, at den hører hjemme i denne kategori.

Udviklingen i NATO og i Vesttysklands forhold til NATO i begyndelsen og midten af 1950 'erne betød, at de to mindretal i realiteten blev placeret $i$ en situation, som vi tidligere har karakteriseret som en form for gensidig gidselsituation. ${ }^{17}$ Som et eksempel herpå kan nævnes, at oprettelsen af det tyske mindretals sekretariat i København i 1983 blev modsvaret af en forøgelse af den slesvig-holstenske delstats tilskud til det danske skolevæesen i Sydslesvig.

Den vigtigste forklaring på denne udvikling er antagelig, at Vesttyskland ikke længere i det danske udenrigspolitiske beslutningsmiljø opfattes som en sikkerhedspolitisk risiko.

\section{Alternative løsninger - og noget om fremtiden}

Uanset hvorledes man vender og drejer det, er de to mindretal - til dels også de nationale frisere, selv om deres forhold af en række grunde er anderledes - fanger af deres situation.

Integrationen i det omgivende samfund, som den moderne samfundsudvikling har gjort det vanskeligere og vanskeligere at kæmpe imod - og som mange i de to mindretal også har set som noget, der havde en selvstændig værdi startede på det økonomisk-sociale område og fortsatte på det politiske. I det lange løb er tendensen til assimilation stærk.

Udviklingen er naturligvis forløbet under forskellige former, fordi de politiske systemer $\mathrm{i}$ de to lande er forskellige, og fordi den samfundsmæssige udvikling ikke har været ens. Men alligevel har grundtrækkene i udviklingen været de samme: Den gradvise udvikling fra det gamle landbrugssamfund via industrisamfundet til nutidens moderne servicesamfund, hvor også den offentlige sektors karakter spiller ind. De unges uddannelses- og karrieremu- 
ligheder i de to samfund minder også om hinanden, idet der begge steder er tale om begrænsninger på grund af regionernes beliggenhed i den geografiske periferi.

Det betyder, at forholdet mellem mindretallets politiske interesser som gruppe og de enkelte mindretalsmedlemmers interesser som borgere i samfundet på mange måder var - og er - af samme karakter nord og syd for grænsen. Begge steder vil der være en klar tendens til, at gruppens og den enkeltes interesser netop ikke er sammenfaldende - måske er de endda modsat rettede.

I denne situation har begge mindretallene betonet det kulturelle - herunder det sproglige - som noget, der i hvert fald var nødvendigt for at holde fast og holde sammen, og det er blevet sagt, at i den aktuelle situation er det kulturelle felt mindretallenes eksistensberettigelse. Indsatsen på dette område er betydelig for alle tre mindretals vedkommende - men det er de kræfter i de omgivende samfunds kulturmønster, som mindretallene er oppe imod, også.

Den økonomiske, sociale og politiske integration - som langtfra er fuldstændig, men dog af stadig større omfang - og som det er svært at komme uden om i det moderne samfund - kan ikke undgå at føre til et fortsat voksende pres på mindretallenes sprog og kultur. Ikke fordi nogen egentlig vil det, men fordi sådan er det. Udviklingen vil naturligvis ikke være ensartet for alle, og den vil ikke komme i samme takt; men den vil uvægerligt gå i retning af en situation, hvor det bliver nemmere - og på nogle områder måske også mere givende - at være så integreret som muligt i den større helhed.

Økonomisk og social integration og politisk samarbejde er tilsammen en proces, der - når den først er gået $\mathrm{i}$ gang - ikke lader sig ændre og der er $\mathrm{i}$ hvert fald ingen vej tilbage til udgangspunktet.

Som fremhæuet $\mathrm{i}$ afsnit 1 har der i løbet af de seneste to-tre årtier kunnet konstateres en vækst $i$ den etniske bevidsthed $i$ relation til mange sproglige, kulturelle og nationale mindretal i Europa. Det er blevet set som et tegn på en modsatrettet tendens, som tyder på, at der i det moderne samfund er plads for - måske ligefrem øget behov for - en forskelligartethed med udgangspunkt for eksempel i regionens særlige forhold.

Dette element forekommer at være stærkere til stede i Sydslesvig end $i$ Nordslesvig. Det er imidlertid vor opfattelse, at de elementer af fremgang eller forsinkelse af tilbagegangen - der kan konstateres for det danske mindretal i Sydslesvig snarere skal sættes i forbindelse med brugen af det danske alternativ som et led $\mathrm{i}$ den almindelige regionalpolitiske proces i Tyskland og Slesvig-Holsten end med en national eller kulturel identitetssøgen $i$ et stadigt større og mere fremmedgørende samfund. 
Det spørgsmål melder sig så, om det i denne situation er muligt at bringe nye politiske løsningsmodeller $\mathrm{i}$ anvendelse, som $\mathrm{i}$ den givne situation kan være hensigtsmæssige for mindretallene - og dermed måske også for flertallene.

Oversigten over de forskellige former for løsningsmodeller viser klart nok, at der ud over den benyttede repræsentations- eller ligestillingsmodel kun kan være tale om at overveje autonomimodellen.

Er en form for kulturel - eller social - autonomi en anvendelig model i relation til de to (tre) slesvigske mindretal?

De områder i Europa, hvor en form for selvstyre - autonomi - er blevet benyttet som løsningsmodel, har normalt været kendetegnet ved, at den relevante befolkningsgruppe har udgjort et flertal $\mathrm{i}$ det pågældende område, selv om den i forhold til hele staten var et mindretal. Gronland, Åland, Nordirland, Baskerlandet og det tyske sprogområde i Østbelgien er eksempler på sådanne områder.

Der kan ikke på samme måde identificeres noget område nord eller syd for den dansk-tyske grænse, hvor enten det tyske mindretal eller det danske mindretal udgør bare tilnærmelsesvist et fiertal i befolkningen. Derfor er det umuligt at argumentere for autonomimodellens anvendelighed i disse tilfælde.

Repræsentations- eller ligestillingsmodellen - gerne suppleret med relevante og liberale former for hensyntagen til mindretallenes specielle forhold - forekommer altså også i fremtiden at være den rimelige og naturlige løsningsmodel, når der tages hensyn til mindretallenes størrelse og koncentration i det slesvigske område.

Den ensartede løsningsmodel, som i Nord- og Sydslesvig er blevet anvendt for at sikre mindretallenes politiske status, har altså i sig indbygget nogle tendenser, der $\mathrm{i}$ de to forskellige sammenhænge, som det danske og det tyske samfund og deres forskellige udvikling reprasenterer, har fort til parallelle resultater $o g$ fremtidsperspektiver for de to mindretal.

Man kan besinde sig på sit kulturelle og identitetsmæssige udgangspunkt, man kan intensivere sit politiske og organisatoriske arbejde for at dæmme op for denne udvikling, og det er sikkert også $i$ et vist omfang muligt at dæmme op for den. Men man kan ikke med nogen rimelighed argumentere for anvendelse af andre løsningsmodeller.

Ud over ressourcer fra den stat, der repræsenterer den kultur, man identificerer sig med, skal de ressourcer, som er nødvendige i dette arbejde, også skaffes fra organer, som flertallet har magten over. Derfor kræver de politisk arbejde og samarbejde under forskellige former med flertallets repræsentanter osv. - altså netop den form for social og politisk integration, som $i$ hvert fald under denne synsvinkel fører til de uheldige tendenser. 


\section{Afslutning - med et forsøg på en teoretisk sammenfatning}

Artiklens problemstilling har været at opstille mulige modeller for løsning af nationale mindretals politiske status. Efter en dreftelse af betingelserne for modellernes anvendelse er forholdene i det slesvigske område blevet anvendt som illustration og som en mulighed for konkret afprøvning. Gennemgangen har vist to ting.

For det første har den vist, at der ikke er nogen simpel overensstemmelse mellem de forskellige typer af mindretal og de forskellige løsningsmodeller for mindretallenes politiske status.

For det andet er det fremgået, at et og samme mindretal på forskellige tidspunkter og $\mathrm{i}$ forskellige perioder kan være stillet over for forskellige løsningsmodeller. Det danske mindretal i Sydslesvig har således i en periode måttet tilpasse sig diskriminations- og undertrykkelsesmodellen og $i$ en anden periode repræsentations- eller ligestillingsmodellen. Hertil kommer, at også grænseflytningsmodellen har været bragt $i$ anvendelse.

Der er altså tale om forhold, der er underkastet en dynamik, der blandt andet er bestemt af den politiske og samfundsmæssige udvikling i det omgivende samfund og - for grænseflytningsmindretallene - $\mathrm{i}$ forholdet mellem de to involverede stater.

Hvad angår det tyske mindretal i Nordslesvig, har Andreas P. Cornett påpeget, at det sociale samspil mellem mindretallets medlemmer nu ikke kan siges at være større, end hvad tilfældet er i forhold til den danske majoritetsbefolkning. ${ }^{18}$ Denne situation kan ses som et resultat af grundlæggende sociale processer - først og fremmest moderniseringsprocesser. Derved er de former for adskillelse og adskilthed (segregation), som er omtalt $i$ afsnit 1, delvis blevet nedbrudt. Dette galder også på det kulturelle felt, hvilket betyder, at der på længere sigt er en alvorlig trussel mod mindretallets fortsatte eksistens. Det tyske mindretal er her $i$ en klar konfliktsituation, idet man på den ene side har et stærkt ønske om social og politisk ligestilling samt social integration og på den anden side lige så naturligt ønsker en fortsat eksistens som sindelagsminoritet. Som det er fremgået, er det på lang sigt en uholdbar situation. ${ }^{19}$ Situationen må nu bedømmes som kritisk også på kortere sigt, idet både mindretallets størrelse og koncentration i bestemte områder er så begrænset, at den af Cornett beskrevne situation må siges at være uundgåelig.

Det danske mindretal og de nationale frisere er underkastet de samme sociale processer og dermed udsat for de samme trusler. Det frisiske mindretal har en sådan størrelse, at situationen på lidt længere sigt må betegnes som alvorlig, men denne befolkningsgruppe har hidtil været begunstiget af en større geografisk koncentration end de øvrige slesvigske mindretal. Fortsatte sociale 
moderniseringsprocesser vil imidlertid kunne ændre dette forhold afgørende. For det danske mindretal er situationen på kortere sigt noget gunstigere, idet det har en sådan størrelse og koncentration, at de demografiske forhold næppe endnu kan siges at have forårsaget en selvforstærkende assimilationsproces.

Træk i den slesvigske udvikling må siges at have mere generel gyldighed. Grundlæggende vil vi pege på, at sociale moderniseringsprocesser vil bevirke en større økonomisk integration i samfundet. I det omfang, dette tillige resulterer i indenlandske befolkningsvandringer, betyder det, at der ikke blot sker en integration af geografisk koncentrerede mindretal, men også, at mindretallets medlemmer som enkeltpersoner integreres i det økonomiske liv - den proces, vi har kaldt økonomisk assimilation, og som må vurderes som den væsentligste enkeltårsag til kulturel assimilation.

Moderniseringsprocesser vil være forbundet med en generel forøgelse af samfundets økonomiske velfærd. Såfremt denne velfærdstigning også omfatter et nationalt mindretal, er dette ensbetydende med en forøgelse af mindretallets ressourcer - også sådanne, som kan omsættes til politisk aktivitet. Er et mindretal udsat for en absolut velfærdsfremgang, men en i forhold til det øvrige samfund relativ tilbagegang, opstår en situation med stigende ressourcer og stigende motivation til politisk aktivitet. Som en sidste mulighed kan moderniseringsprocesserne betyde en absolut velfærdsnedgang for mindretallet og dermed forringede muligheder for at handle politisk. Motivationen for politiske aktiviteter vil derimod være stigende, $\mathrm{og}$ den vil forøges, såfremt mindretallet udsættes for større nedgang end majoritetsbefolkningen.

Det komplicerede forhold mellem moderniseringsprocesser og nationale mindretal er et påtrængende, men uafklaret teoretisk problem. Det falder uden for denne artikels rammer at formalisere denne problemstilling, idet hensigten alene har været at pege på mulige tendenser og udfald $\mathrm{i}$ relation til den slesvigske situation.

Sociale moderniseringsprocesser vil dog uundgåeligt skabe øgede muligheder og i visse tilfælde motivation for øget politisk aktivitet hos nationale mindretal. Det er nærliggende at kanalisere den politiske aktivitet gennem det nationale mindretals organisationer, hvorved mindretallet integreres yderligere, og medlemmernes nationale identitet forøges.

Et nationalt mindretals ønske om en løsningsmodel for deres politiske status synes i europæisk sammenhæng at være begrænset til valget mellem autonomimodellen og ligestillingsmodellen. Valget kan imidlertid ikke træffes uden hensyntagen til de konkrete samfundsmæssige omstændigheder.

Gennemførelsen af autonomimodellen vil således ikke blot være betinget af, at mindretallet er koncentreret til et bestemt geografisk område, men også, at 
det selv er den regionale majoritetsgruppe. Hvis autonomimodellens samfundsmæssige forudsætninger ikke er opfyldt, vil ligestillingsmodellen være den eneste realistiske mulighed for et nationalt mindretal. Situationen er imidlertid ikke uproblematisk. Alene det forhold, at autonomimodellens forudsætninger ikke er opfyldt, er ensbetydende med, at vigtige assimilationsprocesser er virksomme. En konsekvent gennemførelse af ligestillingsmodellen vil i sig selv betyde en mindskelse af den sociale segregation, hvorved assimilationsprocesserne på længere sigt fremmes, og mindretallets overlevelsesmuligheder svækkes tilsvarende.

Der synes således at være den uundgåelige konflikt, at den model, der i en række samfundsmæssige situationer synes at være den eneste tilfredsstillende for et nationalt mindretal, i sig selv har en indbygget tendens til på længere sigt at svække mindretallet og i yderste konsekvens bevirke dets opløsning.

Denne konklusion bør imidlertid ikke være et argument mod ligestillingsmodellen. Forestillingen om, at et nationalt mindretal har samme rettigheder som majoritetsbefolkningen, betyder naturligvis også lige rettigheder til at værne om og bevare egen kultur. I de her omtalte situationer er det netop et tilstrækkeligt argument for at gennemføre ligestillingsmodellen.

Kultur er imidlertid et kollektivt fænomen; opløses kollektivet, vil et forsøg på at fastholde et tilhørsforhold til et nationalt mindretal blive tomt og meningsløst. Forsøget vil let kunne få rituel karakter.

Forholdet kan imidlertid også udtrykkes langt mere positivt: At et nationalt mindretal assimileres betyder, at det nationale tilhørsforhold ændres fra at være et kulturelt, kollektivt fænomen til at være et individuelt fænomen. Det bliver da en del af den enkeltes forudsætninger og baggrund, og det er hverken betydningsløst eller værdiløst.

\section{NOTER}

1. Sociale systemer er sociale helheder, hvis medlemmer $i$ visse henseender har et særligt socialt samspil med hinanden, det, man kalder social interaktion.

2. Definitionsproblemerne er behandlet mere udførligt i Jørgen Elklit, Johan Peter Noack og Ole Tonsgaard, Nationalt tilhorsforhold $i$ Nordslesvig. Resultater fra en interviewundersagelse, Acta Jutlandica XLIX, Århus, 1978, pp. 22-27.

3. Elklit, Noack og Tonsgaard, op.cit.

4. Jørgen Elklit og Ole Tonsgaard, "Elements for a Structural Theory of Ethnic Segregation and Assimilation «, European Journal of Political Research, vol. 12, no. 1 (1984), pp. 89-100.

5. Elklit, Noack og Tonsgaard, op.cit., pp. 99ff.

6. Joseph Rotschild, Ethnopolitics. A Conceptual Framework, New York: Columbia University Press, 1981, p. 249.

7. I Danmark før 1981 nordiske statsborgere, der havde opholdt sig tre år her i landet; siden 1981 er denne ret udstrakt til alle. 
8. Troels Fink, Rids af Senderjyllands Historie, Vi og vor Fortid 11, København: Schultz, 1943/ 1945, p. 41.

9. Hans Andresen og Hans Jessen, "Sproget skal bruges - Dansk i Sydslesvig«, Uddannelse, 21. årgang, nr. 6 (1988), p. 339.

10. Henrik Becker-Christensen, Dansk mindretalspolitik i Nordslesvig. Udformningen af den danske politik over for det tyske mindretal 1918-20, Ả benrå: Institut for Granseregionsforskning, 1984.

11. Blandt andet refereret i Flensborg Avis, 6. maj 1988.

12. Lorenz Rerup, Slesvig og Holsten efter 1830, Kobenhavn: Politikens Forlag, 1982.

13. For eksempel i årbøgerne.

14. Jørgen Elklit, Det tyske mindretals parlamentariske reprasentation. Et responsum, Åbenrå: Bund deutscher Nordschleswiger, 1981.

15. Jørgen Elklit \& Ole Tonsgaard, "The policies of majority groups towards national minorities in the Danish-German border region: why the differences?«, Ethnic and Racial Studies, Vol. 6, no. 4 (1983), pp. 477-491.

16. Ibid.

17. Ibid.

18. Andreas P. Cornett, »Integration eller assimilation: Nationale mindretal i nutidens samfund«, Okonomi og politik, 59. årgang, nr. 3 (1985-86), pp. 225-32.

19. Se hertil også Elklit, Noack og Tonsgaard, op.cit. 